\title{
The third alternative: Latino immigration from the United States to Canada, 1980 to 2009
}

\author{
Edward S. Shihadeh ${ }^{1}$ \\ Frank Trovato \\ Raymond E. Barranco
}

\begin{abstract}
Using a 30-year time series of national-level data, this study examines the determinants of immigration from the United States to Canada among those whose mother tongue is Spanish. Our results reveal that over the last three decades, Spanish mother-tongue immigrants to Canada increasingly originate from the United States. The trend exhibits two basic patterns. Over the long term, there is a rise in Spanish mother-tongue immigrants coming to Canada from the US, which, in a multivariate context, appears to be linked to the rise in the proportion of Latinos in the US population, as well as to the rise in anti-immigration sentiment in the United States. In the short term, such immigration appears to rise in response to economic recessions and to antiimmigration legislation in the United States. Implications of these findings are discussed.
\end{abstract}

Keywords: Latino immigration, time series, Canada, United States.

\section{Résumé}

Utilisant une série temporelle de données nationales vieille de 30 ans, cette étude examine les déterminants de l'immigration américaine au Canada chez les personnes dont la langue maternelle est l'espagnol. Nos résultats indiquent que sur plus de trois décennies, les immigrants de langue maternelle espagnole au Canada partent de plus en plus des États-Unis. Deux modèles de base se manifestent clairement. À long terme, un plus grand nombre d'immigrants de langue maternelle espagnole arrivent au Canada depuis les États-Unis ce qui, dans un contexte multidimensionnel, semble lié à la hausse de la population hispanique aux États-Unis et à un sentiment anti-immigration plus fort dans ce même pays. À court terme, le plus grand nombre d'immigrants semblent provenir des récessions économiques et des lois anti-immigration américaines. Les implications de ces conclusions sont discutées.

Mots-clés : immigration hispanique, série temporelle, Canada, États-Unis.

\section{Introduction}

The US population of Latinos has risen sharply over the last several decades, due in large part to massive immigration from Latin America, Mexico in particular. Some of that immigration was originally a two-way trip, where migrants would come to the US and work temporarily in order to fi-

1. Edward S. Shihadeh, Department of Sociology, Louisiana State University. Email: edsoc@1su.edu. With Frank Trovato, Department of Sociology, University of Alberta, Edmonton; and Raymond E. Barranco, Department of Sociology, Mississippi State University. 
nance a house or a business back home, or perhaps to fund their children's education. After working for a short period in the US, they would eventually return home, only to repeat the trip some time later (Durand and Massey 2006). But an extensive network of border security that was intended to keep undocumented immigrants out, paradoxically, discouraged landed immigrants in the US from returning home, out of fear that they could not return. This unintended consequence of border security, along with high Latino fertility, swelled the Latino population in the United States to the point where Latinos are now the largest minority in the country (American Community Survey 2009).

The rapid population rise of Latinos was met with unease and raised concerns among nativist constituencies about the so-called "immigrant problem." Fueling this concern was a new wave of Latino migration that sent such immigrants to US regions that had never seen a significant Latino population. The official response to this concern was a succession of anti-immigration laws that, cumulatively, placed many Latinos in an ever-tightening circle of restrictions. The legislation was enforced through highly visible and fear-inducing immigration raids on workplaces across the country. At the grassroots level, anti-immigration sentiment boiled over into vicious hate crimes that shook Latino communities. The attacks of September 11th, and the unprecedented economic recession of 2008 , likely added to the groundswell of resentment.

Thus, there are reasons to suspect that the quality of life for many Latinos in the US has deteriorated over the last several decades. Unfortunately, the options for Latinos are limited. They face uncertain prospects if they return to their countries of origin. And if they do return home, they must cope with the daunting task of re-crossing the US border if they decide to migrate again. In light of these limited options, some Latinos have opted for a third alternative-immigrating to Canada. The purpose of this study is to examine, over a thirty-year period, the determinants of US Latino immigration to Canada. First, we dissect the migrant flow of Spanish mother-tongue immigrants entering Canada from the United States between 1980 and 2009. We then examine whether the total Latino migrant stream to Canada increasingly originates in the United States. The final part of our analysis is based on time-series ARIMA models to determine whether this three-decade trend in Latino immigration to Canada from the US is linked to US or Canadian economic indicators with respect to negative public sentiment in the US toward immigration, and period events associated with antiimmigration legislation in the United States.

\section{Background}

Canada's immigration policy before 1960 strongly favoured White settlers of British origin (Stasiulis 1995). But that changed after a growing civil rights mood prompted Canadian authorities to diversify the migrant flow into the country. The implications of that shift in policy were far-reaching. Three decades later, only 20 per cent of Canadian immigrants were European, while the rest were from Central and South America and elsewhere (Siemiatycki and Isin 1997). But Canada's immigration policy, as well as the makeup of its immigrant population, is influenced not just by internal policy decisions but by external events as well. For example, a complex border security arrangement between Canada and the United States was established after the attacks of 9/11. And back during America's Vietnam conflict, war-resisters seeking refuge from the draft comprised the largest immigrant group entering Canada in the late 1960s (Hagan 2001). So immigration to Canada can at times be influenced heavily by events to the South. 
A more recent example of US influence on Canadian immigration concerns the recent but dramatic rise in the Latino population in the United States. In just the last twenty years, the Latino population in the US increased by more than in all previous years combined. In 1970, they counted for just one in twenty; today they are nearly one in six (Martin and Midgley 2010). This rise occurred in part due to a change in US government policy, which in turn caused a change in the migration patterns of Latinos. Before 1986, Mexican immigration to the US was a balance largely between economic push factors in Latin American countries, labor pull in the US, and the rational choice calculus of individual movers (Durand and Massey 2006). In contrast to popular misconception, not all Mexican migrants were moving permanently to the US for a better life. On the contrary, until 1986 many Mexican immigrants moved to the US temporarily, in order to finance projects back home, like a house, or a business (Durand and Massey 2006). In other words, some immigration across the US-Mexico border was a circular, two-way trip, regulated in part by the temporary economic needs of individual migrants.

But in 1986 the Reagan administration rode a wave of US nationalism and redefined immigration as a national security issue, in order to signal that the nation was being protected in an era of Latin American insurgency (Massey et al. 2002). The resulting Immigration Reform and Control Act (IRCA) of 1986 dramatically expanded border control and criminalized the hiring of undocumented workers (Calavita 1992). Suddenly, it became too risky for many Latino undocumented immigrants in the US to return to Mexico and elsewhere in Latin America, for fear that they could not return (Massey et al. 2002). So those who came, stayed. This change in migration (along with high fertility) increased the Latino population from 14.5 million in 1980 to 47 million in 2009 (American Community Survey 2009), making it the largest minority in the country.2

Employers at first welcomed Latino immigrants with open arms. A booming US economy in the 1990s had created a serious shortage of low-skill labor, and Latino migrants were well-positioned to enter these job markets. Indeed, they have a low reserve wage (Waters 1995; Wilson 1996); they are viewed favorably by prospective employers (Yoon 1997); they are embedded in established networks which facilitate employment and streamline migration (Aguilera and Massey 2003); and they have a strong tradition of entrepreneurship which is invoked to hire their own (Bailey 1987; Hansen and Cardenas 1988). So a rise in the US Latino population was fueled by bountiful jobs, a willing and able migrant labor force, receptive US employers, and a US border policy that produced exactly the opposite of its intended effect.

But immigration reform not only trapped migrants in the United States, it began to degrade the migrants' quality of life. For instance, because of reform, prospective employers were required to keep records confirming their employees' right to work in the country - the I-9 form, which imposed a costly blizzard of paperwork on employers that could only be offset by reducing immigrant wages (Cobb-Clark et al. 1995). So in another irony, employers continued to hire undocumented immigrants but for substantially less money, a trend which cascaded into lower wages for documented migrants as well. Although wages of documented Latino migrants were declining slightly prior to immigration reform, the decline afterward was about four times as large (Massey et al. 2002). In concert with slumping wages was a rise in joblessness among Latino migrants. Massey et al. (2002) find that the proportion of undocumented immigrants not holding a job in the US rose from 11.5 per cent during the pre-reform period to 19.5 per cent after reform, despite the economic upturn during the 1990s. Likewise, the proportion of non-workers rose from 16 to 29 per cent during the same period, most of whom were children. So life in some Latino communities began to get worse.

2 Although immigration contributes to the growth of the US population of Latinos, Latino birth rates now contribute more (Johnson and Lichter 2008). 
Latino immigrants traditionally headed to the Southwest, Florida, Illinois and New York, to settle in concentrated immigrant communities (Durand et al. 2000). The benefits of concentrated immigration areas are well understood. Portes and Jensen (1992) describe areas as dense networks of groups and like-minded people that offer social and economic opportunities not available in mainstream society. The benefits of this arrangement are supported widely in the literature on social capital, for instance, in that people who live in a familiar and well-integrated environment tend to be more socially and culturally connected to their communities and will live happier and healthier lives (Putnam 2000). But in the early 1990s, a growing outcry over the flow of undocumented migrants led the US government to massively blockade two entry points in San Diego and El Paso (Nevins 2002). But rather than stemming the flow, the blockade simply deflected migrants away from traditional settlement states toward other parts of the country. With their traditional gateways blocked, immigrants began entering the US through Arizona and New Mexico and then fanned out to new destinations, where they were being actively recruited by employers (Johnson-Webb 2002).

Other factors, besides border enforcement in the Southwest, encouraged this change in the flow of Latino migration. Whether documented or not, Latino migrants were lured by the robust economies across the Old South and elsewhere. Kochhar et al. (2005) report that

... across a broad swath of the region stretching westward from North Carolina on the Atlantic seaboard to Arkansas across the Mississippi River and south to Alabama on the Gulf of Mexico, sizeable Hispanic populations have emerged suddenly in communities where Latinos were a sparse presence just a decade or two ago" (Kochhar et al. 2005: i).

Moving beyond the American South, Latino immigrants spread out from the Pacific Northwest to communities in the Atlantic Northeast (Suro and Singer 2002). This was a critical milestone in Latino immigrant history, when their immigration transformed from a local to a national phenomenon (Durand et al. 2000).

Unfortunately, these new Latino communities are a far cry from those in traditional destinations. In contrast to traditional Latino communities, new Latino destinations are often little outposts, a collection of trailers or an off-the-radar rooming house teeming with young migrant workers. Unprotected by the umbrella of social control in traditional immigrant communities, Latinos in new destinations face a number of serious problems. For instance, compared to Latinos in old destinations, those in new destinations are twice as likely to be murdered (Shihadeh and Barranco 2013). In some new destinations, the Latino murder victimization rate is as high as that of Blacks. Emblematic of this wave of victimization is a widely reported hate crime in 2008 in which four white teens in Shenandoah, Pennsylvania, killed Luis Ramirez, a migrant worker from Latin America (The Associated Press 2009). More often, though, Latinos are victimized not because of hate, but because of money. Unwilling or unable to engage the formal economy, day-labourers in post-Katrina New Orleans work for a wad of cash at the end of the day. This makes them vulnerable to predatory street thugs, who are attracted not just to the cash, but by the reluctance of these workers to report the crimes (Nossiter 2009). This supports the statistical evidence that Latinos are not only more likely to be robbed than non-Latinos, they are also more likely to experience "secondary violence" as a result of the robbery, like getting beaten and stabbed (Thornton 2010). Their lack of fluency in English only makes matters worse and exposes them to even more violence (Shihadeh and Barranco 2013). For instance, should they fail to understand the robbers' (English) commands, or hesitate for a split second because of the language barrier, the migrant workers are at risk of being shot.

As these small, isolated communities sprang up over the countryside, they also learned to live in fear of immigration authorities. In Postville, Iowa, for instance, migrants from Guatemala found jobs 
at a meatpacking plant. But a crushing recession in 2008 imposed severe unemployment, prompting Homeland Security agents to raid the plant and arrest nearly 400 people (Preston 2008). The plant managers were also arrested, convicted, and sent to jail. The plant itself, submerged by millions in fines, declared bankruptcy, putting even the legal Latino workers out of work. Such workplace raids led to other troubling consequences, as when a court in Missouri removed the parental rights of a Guatemalan woman after she was arrested during such a raid. The court awarded custody of her 6-month-old son to another couple, without the natural mother's consent (CNN 2011). If this is the new migration writ small, then Postville and Missouri are as tributaries in a broader employment underworld, where significant numbers of migrant workers float from one cash job to another, under the threat of apprehension for being undocumented or at risk for helping those who are.

The cases have a calculated visibility that sent shockwaves through migrant networks and added to a sense of unease in Latino communities. According to the Pew Hispanic Center, Latinos in general are concerned about the increased public attention toward immigration and the resulting enforcement measures (Pew Hispanic Center 2007). They also find that over half of Latino adults are concerned that a family member or a close friend will soon be deported. And three-quarters of them disapprove of workplace raids like those in Postville. Another report—after the start of the recession-reveals that one-third of all Latinos are worried that they will lose their home to foreclosure (Lopez et al. 2009). They also face serious restrictions on social services like health insurance. Among the total US population, 17 per cent lack any form of health coverage, compared to 28 per cent among documented Latinos and 60 per cent among undocumented Latinos (Livingston 2009). In other words, between one-third and one-half of the nation's largest minority has no insured medical care.

The Postville raid, the adoption scandals and the murder of Latino immigrants were paralleled by organized legislative efforts to stem illegal Latino immigration into the United States. In the late 1990s and early 2000s, there was a series of state-level initiatives that declared states as "English only" and removed support for "experimental language programs" [read: bilingual-Spanish]. These include Proposition 227 in California (State of California 1998), Proposition 203 (State of Arizona 2000; Mahoney et al. 2004), and elsewhere. These were followed by local ordinances across the country that authorized city governments to impose fines on landlords and business that rent or hire illegal immigrants (cf. Armor 2006). Later, state governments themselves concocted their own immigration policies and aggressive enforcement initiatives, such as the widely known and highly restrictive Arizona law, SB 1070 (State of Arizona 2010). By our count, about half the states in the union have passed or are considering similar initiatives. Although the local ordinances have been struck down as unconstitutional by federal judges (Preston 2007), and the state-level efforts are being challenged now, the political and social impact of these efforts resonates widely. It signals to Latino communities that their presence in the United States is increasingly resented.

The US border with Mexico is interesting in several respects. It is massive, some 2,000 miles across, and it demarcates a huge economic differential, with the world's richest economy on one side and a very poor one on the other. The US border with Canada, on the other hand, receives little attention in the academic or policy literature. But it is a border that offers Latinos in the US a route to a less troubled economy and an escape from anti-Latino violence and the vitriol that increasingly characterizes the public discourse on immigration. With their southern escape route sealed off, and facing an ever-tightening circle of immigration restrictions, Latinos dissatisfied with life in the United States may find in Canada a realistic third alternative. The neighbour to the north, Canada, is a global-immigrant society that is less fixated on external threats. It offers generous social services, a high standard of living, and an economy less buffeted by the global recession. There is also a 
thriving Latino enclave in Toronto to help assimilate the newcomers (Siemiatycki and Isin 1997). On the downside, Canada's immigrant communities are more vulnerable to poverty than is the general Canadian population (Kazemipur and Halli 2001). In addition, research on Latino migrant women in Canada reveals that they often experience separation from their children, leading to the creation of transnational families (Bernhard et al. 2008). Unfortunately, there is a dearth of research on this issue, even though Latino immigration to Canada is accelerating. Whereas those whose mother tongue was Spanish (from any country) were the 10th-largest group entering Canada in 1999, they grew to be the 4th-largest by 2007 (Statistics Canada 2008). Based on anecdote, at least, members of Toronto's Latino community seem convinced that divisive gate-keeping policies in the US are pushing Latinos northward (Grewal 2007).

The number of Spanish mother-tongue immigrants entering Canada from the US is still small when compared to overall immigration to Canada. But despite the small numbers, we justify the study on several grounds. First, as the following analysis reveals, the increase in such immigration has risen dramatically, increasing some twentyfold, or by 2,000 per cent, in the last 3 decades. Second, this trend shows no signs of ebbing. The resentment in the United States toward Latino immigration is palpable and may intensify even further as the economy remains in recession. And despite Federal objections and challenges, State governments in rapidfire succession have passed legislation that constricts opportunities in Latino communities. This analysis offers an early glimpse into a process that bears directly on Canada's immigration future. Indeed, small numbers have often been used to study major issues. ${ }^{3}$

In summary, the discussion above suggests that Latino immigration from the US to Canada is increasing due to a number of factors that are degrading the quality of life for Latinos in the United States. Accordingly, this study dissects the migrant flow of Spanish mother-tongue migrants entering Canada from the United States between 1980 and 2009. Initially, we examine the basic question of whether the total Latino migrant stream to Canada increasingly originates in the United States. Then, using time-series ARIMA (Auto-Regressive Integrated Moving Average) models, we examine whether this three-decade trend in Latino immigration to Canada from the US is linked to US or Canadian economic indicators, negative public sentiment in the US toward immigration, and/or period events like anti-immigration legislation and so forth. We then discuss the implications of our findings.

\section{Data and methods}

The unit of analysis is at the national level for both Canada and the United States. Unless otherwise stated, the time period for all variables in the analysis is from 1980 to 2009, which covers several major milestones in the social, economic, and political history that are potentially relevant to USbased Latinos. Data on US-to-Canada immigration, disaggregated by country of last residence and mother tongue, was obtained through a special extract from Citizenship and Immigration Canada (CIC) for the 1980 to 2009 time period (CIC 2010). Despite the usefulness of CIC data we caution that they can be influenced by administrative processes that lie outside our predictive models, such as annual targets for immigration and availability of personnel that process entrance applications.

3. Criminologists do this all the time. For example, there are about 600 murders a year in Canada — a small fraction of total Canadian crime, far fewer than the annual number of US Latinos immigrating to Canada, and (thankfully) have not grown twentyfold in the last several decades — and yet homicide today is an institutionalized topic of interest. 
Population data for the Latino population in the United States are from the US Census of Population and Housing for 1980, 1990, and 2000, as well as from inter-census published estimates between 1980 and 2009 (US Census Bureau 2010). Canadian population data are from the Census of Canada for 1981, 1986, 1991, 1996, 2001, and 2006, and published estimates for inter-census periods (Statistics Canada 2001; 2006). US unemployment and other economic indicators are from the US Bureau of Labor Statistics (2010), while Canadian labour force data are from Statistics Canada's Labour Force Survey (Statistics Canada 2010). Data on US public opinion regarding Latinos is from polls conducted by Gallup, Inc. (Morales 2010).

\section{Dependent variable}

The variable names as listed in the tables are indicated here in bold. The dependent variable is the yearly proportion of all Spanish-mother tongue immigrants to Canada who originate from the United States during the thirty year interval (US Latino Immigration to Canada). Although Latino immigration to Canada from the US is rising, especially during the last decade, the United States is not the largest source of Latino immigration to Canada.4 By far most come from Columbia, no doubt because of Columbia's security problems and exceedingly high rate of violence (McDermott 2003; CIA 2010). Because the large number and sharp rise in Latino immigration from Columbia can influence the observed proportion of Latinos from the US, we run the models with and without Columbian immigrants. Although both methods produce identical substantive results, we report only those that exclude Columbian immigrants.

\section{Independent variables}

Our wish-list of potential predictors is narrowed by several factors. First, a continuous 30-year time series of national-level data is available only for selected variables. Many occasional surveys are substantively interesting, but are unsuitable for this analysis because of their cross-sectional design. Second, we had to narrow the list of predictors in order to avoid multicollinearity, a common problem in aggregate-level analysis. As the unit of analysis gets larger, within-unit variation in substantive variables increases while, unfortunately, across-unit variation decreases. For our time series analysis, this implies that two variables are more likely to be correlated over time at the national level than at, say, the county level.

The resulting predictors are as follows: In order to measure job prospects and economic conditions more broadly, we include the US Unemployment Rate. This is the proportion of those in the US labour force who are currently not employed. Likewise, we also measure the Canadian Unemployment Rate in order to reflect analogous conditions in Canada. ${ }^{5}$ The proportion of all immigrants to Canada

4 Although we occasionally use the term Latino in the paper, we insert the following caveat. Strictly speaking, Latino refers to those from Latin American countries. But we use the term Latinos in a broader sense, referring to those who self-identify with a group in the United States whose culture and language can be traced to a Spanish-speaking country, and who make up the rich spectrum of people who are now the largest minority in the United States. We also recognize that our measure of Spanish mother tongue does not mesh perfectly with that identity, and that the two are distinct concepts. Mother tongue, by Canadian recording standards, refers to the first language learned as a child and still understood by the individual at the time the information is recorded. Obviously, one can self-identify as Latino and not have learned Spanish as a child, or have learned it as a child and lost it in adulthood.

5 We considered including GDP levels in both the US and Canada, but closer analysis revealed that they were highly correlated with each country's unemployment rate. Similar analysis revealed that the Latino unemployment rate was highly collinear with overall US unemployment. Although both predictors yielded the 
who originate from the United States is included (Total US-Canada Immigration) in order to control for the volume and trends in the overall flow of US-to-Canada immigration. There are doubtless global factors that influence the likelihood that any US-based resident, regardless of ethnicity, would move to Canada. We filter out these influences in order to distill the specific predictors of Latino immigration from the US to Canada. We also control for the proportion of the US population that is Latino (US Latino Population). It is conceivable that US Latino immigration to Canada may be driven by sheer demographic momentum and the dramatic rise in the US population of Latinos.

We also include the proportion of Latino migrants who return bome within one year after arriving in the United States. This variable was obtained from a survey of Mexican migrants by the Mexican Migration Field Research and Training Program at UC-San Diego (Cornelius et al. 2008). The survey documents the effectiveness and impact of US border enforcement strategy and contains data for the thirty-year period in question. We use this as a proxy to measure the extent to which US-based Latinos are willing to return home through Mexico, as an alternative to either staying in the United States or moving northward to Canada. The variable, though highly useful, has some limitations. First, it only measures migrants from specific provinces in Mexico and so is not representative of the full US population of Latinos. Second, it only surveys those travelling through the San Diego crossing, which being a traditional route to an old Latino destination, does not cover the full spectrum of Latino life in the United States. We interpret the results cautiously with these limitations in mind.

Obtaining long-term data on the increasingly heated debate about immigration in the United States proved surprisingly difficult. Unfortunately, the General Social Survey, which has gathered opinion data since 1985 on a wide swath of public issues, has no time series data on Latinos or on immigration more broadly. Instead, we use a long-running poll on immigration from Gallup, Inc. Their specific question is "Should immigration be kept at its present level, increased, or decreased?" We calculate the proportion of respondents who answered "decreased" to that question (anti-immigration sentiment). ${ }^{6}$ The question has been asked often since 1964, but not every year. For the period 1980 to 2009 , the coverage is spotty for the first half of the period, and nearly continuous for the second half. Using a linear interpolation, we impute values for the following years: 1980-1985 (using data from both before and after that period), 1987-1992, and for 1996-1998. However, as immigration became a growing public concern, the question was asked more frequently, sometimes more than once in a single year. Indeed, Gallup asked the question 16 times in the last nine years alone. In multiple-survey years, we average the results over the year.

Despite some missing data during the first half of the time series, we are confident that our values reflect the overall trend in public opinion for several reasons. First, other immigration surveys conducted during the years with missing data show little change in public opinion. For instance, when Roper asked whether an all-out effort should be made to stop illegal entry into the United States, 91 per cent agreed in 1980, and 89 per cent agreed five years later, in 1985-nearly identical figures. Likewise, when a CBS/NYT poll asked whether a new immigrant moving into your neighborhood would be welcomed, 68 per cent agreed in 1986 and 67 per cent agreed in 1993 (Lapinski et al. 1997). Second, survey organizations are businesses that must justify their costly services on economic grounds. It is unlikely that an immigration question will be asked when the issue is off the

same substantive results, we opted to include the latter in order to have analogous labour force measures in both the US and Canada.

6. We would have preferred a question more specific to Latinos but none was available. Nonetheless, our informal observations suggest that US public opinion about immigration is nearly indistinguishable from attitudes about Latinos. This may explain why modern-day anti-immigration legislation is often closely tied with anti-bilingual (anti-Spanish) legislation that declares certain local areas as "English only" (Johnson 2009). 
public radar and/or when public sentiment about immigration is unlikely to change. For that reason, we suspect that the first half of our time series, despite some missing points, adequately reflects the trend in US public opinion regarding immigration.

Time series analysis also allows us to model non-time series events and those with a brief or one-time impact. These are commonly referred to as "intervention" variables. We include two such intervention variables. The first event variable is shock effect of the Sept. 11 attacks. Since this occurred in the ninth month of 2001, we code both 2001 and 2002 as a 9/11 effect. ${ }^{7}$ Second, we include an immigration legislation intervention variable to reflect the years in which strict, national-level and highly visible immigration laws were passed. ${ }^{8}$

We estimate our time series using ARIMA. ARIMA is a general class of models for estimating and forecasting time series models. The procedure essentially stationarizes a time series of data through transformations such differencing, and then fine-tunes the fit by lagging the differenced series in order to remove any traces of autocorrelation, which is inherent to time series data. In formal terms, a non-seasonal ARIMA model is classified as ARIMA $(p, d, q)$, where $p$ is the number of autoregressive terms, $d$ is the number of nonseasonal differences, and $q$ is the number of lagged errors in the prediction equation. The best fit is determined by maximizing the stationary R-squared which, for interpretation purposes, is analogous to the R-square in OLS and reflects the proportion of explained variance in the dependent variable explained by the model. The residual fit is determined by the Ljung-Box indicator (also known as the modified Box-Pierce statistic). This gives an indication of whether the model is correctly specified. A significance value of less than .05 suggests that there is empirical structure in the series that is not accounted for by the ARIMA $(p, d, q)$ model. Conversely (and desirable), significance values closer to 1.00 indicate no identifiable pattern in the residuals, and is an inferential test that the model is correctly specified (Box et al. 1994; Brockwell and Davis 2009).?

\section{Results}

Table 1: Descriptive Statistics of Latino Immigration to Canada, 1980 to 2009.

\begin{tabular}{lcc}
\hline & Mean & $\begin{array}{c}\text { Standard } \\
\text { Deviation }\end{array}$ \\
\hline Anti-Immigration Sentiment in US & 50.8 & 7.3 \\
US Latino Immigration to Canada & 2.2 & 1.2 \\
Total US- Canada Immigration & 4.3 & 2.1 \\
US Unemployment Rate & 6.2 & 1.5 \\
Canadian Unemployment Rate & 8.6 & 1.7 \\
US Latinos Return to Latin Amer. & 9.6 & 3.9 \\
US Latino Population & 10.7 & 2.9 \\
\hline
\end{tabular}

EVENTS: US Immigration Legislation 1986, 1994, 1996, 2002, 2005.

Sept. 11 Attacks 2001, 2002.

Table 1 shows the descriptive results of the variables used in the analysis. Over the 30-year time period, an average of 2.20 per cent of Spanish mother-tongue immigrants to Canada came from the

7. In this manner, the 9/11 attacks are modeled as a single shock event. We also modeled it as a continuous shock, starting in 2001 and continuing to the end of the study period. The latter was not significant.

8. 1986 - Immigration Reform Control Act; 1994 - Operation "Hold the Line" and "Operation Gatekeeper"; 1996 - Illegal Immigration Act; 2002 - Enhanced Border Security and Visa Form Act; 2005 - Real I.D. Act.

9. Box and Jenkins (1976) recommend a minimum of 50 points in a time series for the purpose of forecasting with ARIMA models. Although our data is, unavoidably, less than that minimum threshold, the purpose of our analysis is not forecasting. 


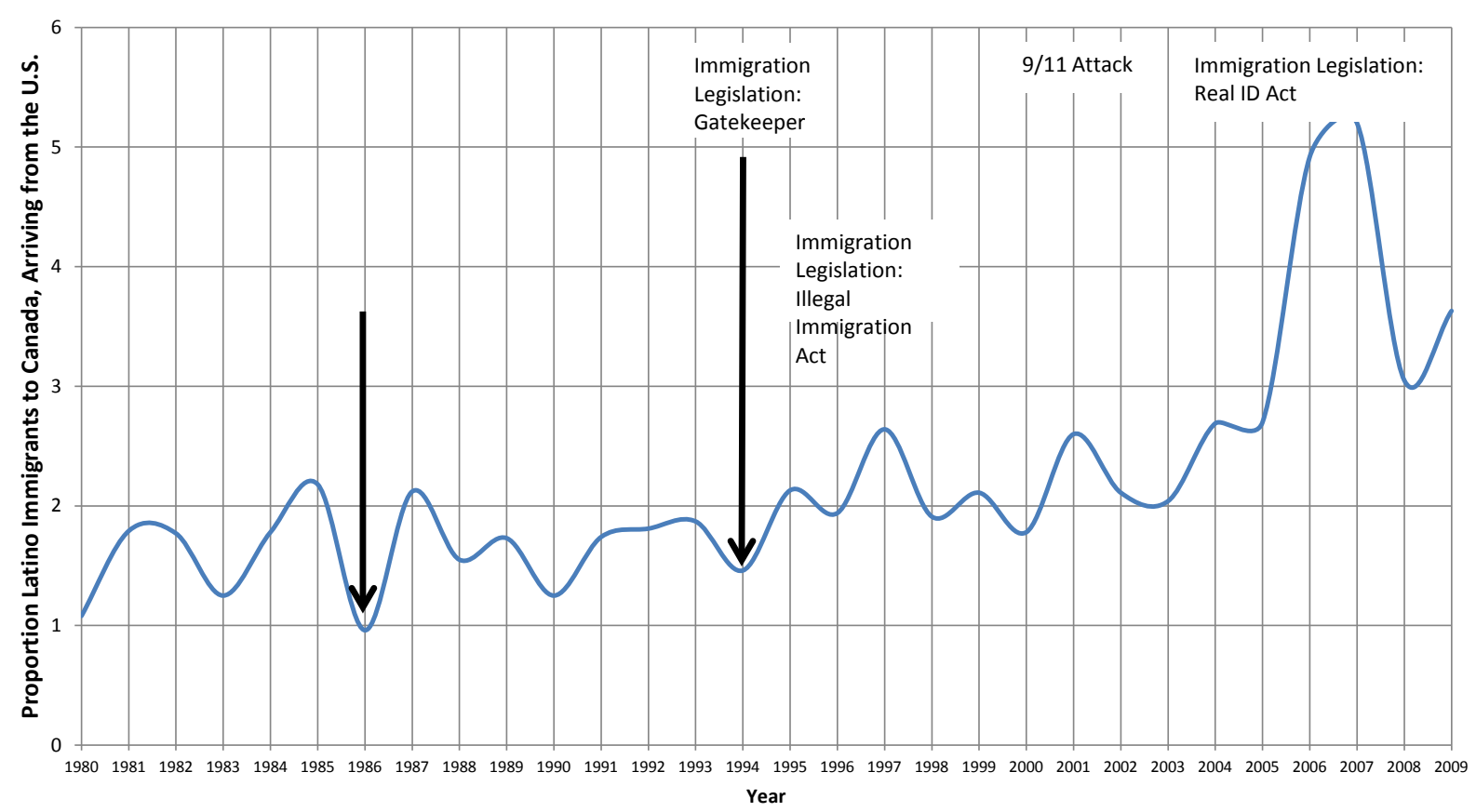

Figure 1: Predicted proportion of Spanish-speaking immigrants to Canada arriving from the US, $1980-2009$.

Unites States (US Latino immigration to Canada). Note, however, there is considerable variation in that result. Closer analysis reveals that the lowest level was in 1985 (.85 per cent) while the highest value was only recently, in 2006 (6.40 per cent). In general, US Latino immigration to Canada has risen over the three-decade time period, a trend that can be more clearly seen in Figure 1, which we discuss at length later in this section. This is in contrast to the declining trend in total US immigration to Canada (the share of all Canadian immigrants who originated in the US, regardless of mothertongue or ethnic origin). In 1981, about 8 per cent of all immigrants to Canada came from the US, whereas in 2009 it is down to less than 4 per cent. Another variable with a declining trend is the proportion of Latino immigrants to the United States who return home to Mexico within one year. Although Table 1 indicates an average of 9.57 per cent, it actually declined from over 20 per cent in the early 1980s to just over 6 per cent in 2009. This supports the view that an unintended consequence of border enforcement was to reduce the likelihood of circular or two-way migration in favour of more permanent stayers in the United States.

Table 2: Model Fit, ARIMA ANALYSIS.

\begin{tabular}{cccccc}
\hline & \multicolumn{2}{c}{ Model Fit } & \multicolumn{3}{c}{ Ljung-Box } \\
\hline Model Type & $\begin{array}{c}\text { Number of } \\
\text { Predictors }\end{array}$ & $\begin{array}{l}\text { Stationary } \\
\text { R-squared }\end{array}$ & Statistics & DF & Sig \\
\hline ARIMA $(2,0,1)$ & 8 & 0.814 & 8.389 & 15 & 0.907 \\
\hline
\end{tabular}

Table 2 summarizes the model and its fit statistics. The optimized model is an ARIMA $(2,0,1)$, which provided the best fit, or highest stationary R-Square. The stationary R-Square in this model is 0.814 , indicating that over 81 per cent of the year-to-year variation in US Latino immigration to Canada is accounted for by the model and the 8 predictors. The Ljung-Box test is far from significant 
Table 3: ARIMA Model parameters predicting US Latino immigration to Canada, 1980 to 2009.

\begin{tabular}{lrrrr}
\hline & Estimate & Standard & $\mathrm{t}$ & Significance \\
\hline US Latino Immigration to Canada & -8.111 & 4.087 & -1.984 & 0.063 \\
AR: Lag 1 & 0.523 & 0.266 & 1.969 & 0.065 \\
AR: Lag 2 & -0.609 & 0.235 & -2.585 & 0.019 \\
MA: Lag 1 & 0.998 & 22.307 & 0.045 & 0.965 \\
& & & & 0.021 \\
Anti-Immigration Sentiment in US & 0.081 & 0.032 & 2.518 & 0.028 \\
Total US-to-Canada Immigration & 0.392 & 0.164 & 2.397 & 0.472 \\
Canadian Unemployment Rate & -0.116 & 0.158 & -0.734 & 0.749 \\
No. US Latinos Return to Mexico & 0.036 & 0.111 & 0.324 & 0.003 \\
US Latino Population & 0.530 & 0.153 & 3.467 & 0.816 \\
US Unemployment Rate & -0.051 & 0.216 & -0.236 & 0.002 \\
Sept. 11 Attacks & -1.726 & 0.486 & -3.552 & 0.519 \\
US Immigration Legislation & -0.261 & 0.396 & -0.658 & \\
\hline
\end{tabular}

(0.907), increasing our confidence that the model is correctly specified and that there is no identifiable structure in the variance that is unexplained by the model.

Table 3 summarizes the parameter estimates of the individual predictors. There are four predictors that emerge as significant at the 0.05 level. The first is anti-immigration sentiment. The positive parameter estimate (0.081) suggests that when the US public attitude turns negative and favours restricting immigration, then US-originating Latinos make up a greater share of overall Latino immigration to Canada. This is consistent with the view that US Latinos are migrating to Canada in part because of the anti-immigration atmosphere in the United States. Second, Latino immigration from the US to Canada is positively related to the overall volume of immigration from the US to Canada, regardless of ethnicity or linguistic origin (0.392). Whatever global factors influence US-to-Canada immigration among the total population, seem to reverberate among Latinos as well. Third, the Latino migrant flow from the US to Canada is also influenced by the sheer mass of the Latino population in the originating country. The parameter estimate of 0.530 suggests that a one-percent rise in Latino proportion (in the US) is linked to an increase of about half a percent in Latino immigration to Canada.. Finally, we see a 9/11 effect. The negative parameter $(-1.726)$ for the September $11^{\text {th }}$ attacks indicates that the attack was followed by a reduction in Latino immigration to Canada. We discuss this finding in more detail below.

In the next phase, we examine further the potential impact of the two intervention variables, but in a different way. In Figure 1, we plot the predicted level of US Latino immigration to Canada based on an ARIMA model that includes the time-series variables only; the intervention variables are not included. The predicted, or smoothed, values of the dependent variable are plotted in Figure 1. In other words, Figure 1 displays the predicted yearly values for the variable "US Latino immigration to Canada" from a model that includes all the variables except the 9/11 attacks and immigration legislation. These two intervention variables are instead visually superimposed at the appropriate time point on the plot. The figure reveals two trends in the data, one long-term and one short-term. The longterm trend indicates that Latino immigrants to Canada are increasingly originating from the United States. But the figure also reveals short-term fluctuations that are highly responsive to specific events. For instance, the passage of immigration legislation triggers an immediate rise in immigration, followed by a recovery that is incomplete. The first increase came after IRCA, the widely known and transformative immigration during the mid-1980s that, for the first time, defined immigration as a national security question. The recovery from this rise, however, was only partial. The largest rise in 
Shihadeh et al.: The third alternative—Latino immigration from the United States to Canada, 1980 to 2009

Latino immigration appeared in the 2000s, immediately after the passage of the 2002 Visa Form Act and the 2005 Real ID Act. The latter legislation seeks to standardize ID standards throughout the country. In the absence of a national ID, the Real ID Act imposes a federally mandated standard for driver's licenses. The act also funds a vast inter-state data-sharing system as another bulwark against fraud and illegal immigration. Moreover, it imposes a heavy burden of proof on immigrants who apply for a driver's license, requiring them to produce extensive corroborating evidence of citizenship. Finally, the legislation provides more funds for the border fence and grants waivers of laws that interfere with its construction. Facing some state challenges, the Real ID Act is not yet fully enforced. But for undocumented migrants, the its intent and potential threat loom large. If enacted, it will become nearly impossible to secure a fraudulent ID that can pass federal standards. And measures such as these create a net increase that, over the long haul, will permanently swell the Latino migrant stream from the US to Canada.

\section{Discussion and conclusion}

Using a 30-year time series of national-level data, this study examines the determinants of immigration to Canada among Latinos based in the United States. Our results reveal that over the last three decades, Spanish mother-tongue immigrants to Canada increasingly originate from the United States. The trend exhibits two basic patterns. Over the long term, there is a rise in US Latino immigration to Canada that, in a multivariate context, appears to be linked to (1) a rise in anti-immigration sentiment in the United States; (2) a rise in the proportion of Latinos in the US population; and (3) the general immigration flow from the US to Canada. In the short term, such immigration responds to period shocks like the 9/11 attacks, which resulted in a drop in Latino immigration. Conversely, the passage of anti-immigration legislation in the United States appears to precipitate a spike in immigration, followed by only a partial decline. We discuss the implications of these findings.

First, it appears that US Latino immigration to Canada will continue to rise, and may account for an increasing proportion of all Spanish-origin immigrants to Canada. Our reasoning is threefold:

1. Based on momentum alone, the long-term trend (not including short-term shocks) reveals a gradually building immigration stream. Back in the early 1980s, US Latinos to Canada entered at a rate of about 50 to 80 migrants per year. By the late 2000s, however, that number increased to roughly 500-1,000 migrants per year, or a twentyfold increase.

2. Because increases in Latino immigration to Canada are partly a response to anti-immigration sentiment in the United States, the flow of US Latino immigration to Canada should continue, since such sentiments in the US show no signs of ebbing.

3. Latino immigration to Canada is linked positively to the rise in the US population of Latinos. Since this population rise is forecast to continue, the flow of US Latinos to Canada may, likewise, continue to build.

Second, this study actually underestimates the "US effect" on Latino immigration to Canada. We study only the immigration to Canada among Latinos residing in the United States. Doubtless, there are Latinos who immigrated directly to Canada, bypassing the United States entirely because of its divisive gatekeeping polices and its deteriorating appeal for immigrants. Indeed, there is a new and growing migrant flow of workers from Latin America to Northern Europe (Millman and Vitzthum 2003) and from Latin America to Southern Europe-Spain and Portugal in particular (Padilla and Peixoto 2007)—and from Ecuador to Israel (Kalir 2005). These developments suggest that as the 
United States declines as a viable immigration destination, other alternatives such as Canada may become increasingly favourable.

Third, although predictions always contain uncertainly, future trends in US Latino immigration to Canada can be informed in several ways. For long-range planning, Canadian immigration officials should monitor both Latino population trends in the US along with that country's public mood on immigration. In the short term, fluctuations within a narrow window are responsive to the passage of anti-immigration legislation. According to visual results, passage of US immigration legislation may signal three things: (1) that a rise in Latino immigration to Canada is forthcoming; (2) that the surge may last a year or two; and (3) the rise will be followed by a decline but not to previous baselines.

Fourth, the flow US Latinos to Canada has implications for the discourse surrounding the North American Free Trade Agreement (NAFTA). Research reveals that while NAFTA has produced positive economic outcomes for the United States, the same cannot be said for Canada (Globermann 1999). As a result of NAFTA, Canada has incurred a multi-billion dollar net deficit in professional and management human capital as Canadians moved to the United States (DeVoretz and Laryea 1997). In population terms, for every US resident moving to Canada, there are three Canadians moving to the United States (Iqbal 2000). Although this paper is about the quantity, not quality, of the Latino immigrants to Canada, future research should consider that Latino immigration to Canada is a potentially important counter-flow which may partly offset the human capital losses caused by NAFTA. In plain terms, America's loss may be Canada's gain. Future research should examine this question.

Fifth, although this study considers immigration legislation in the United States, future research should bring Canadian immigration laws into the equation. Of particular note, one provision of the latest immigration act may work against Latino immigration from the United States. The Canadian government, after passing the Immigration Act of 1976 (and subsequently amending it more than thirty times) enacted a fresh new law, the Immigration and Refugee Protection Act of 2001. This law tightens rules on the so-called business-class immigrant by requiring that such applicants have at least five years of business experience, a gross corporate income of $\$ 500,000$ (or over $\$ 41,000$ in monthly gross receipts), and a net personal reported annual income of $\$ 50,000$. The type of business owner this provision is intended to lure fits well with the small business renaissance in the United States ten years ago, a renaissance in which Latino immigrants entrepreneurs played no small part. But the brutal recession in 2008 depressed business revenues across the board, making the new provision an almost unattainable standard of admission for US Latinos.

Sixth, in an historical sense, this is a story of how Canada, once again, is a potential refuge for (among others) those fleeing oppression/injustice/problems in the South. In the 19th century, Canada was the last stop on the Underground Railroad, which led Southern Black slaves to freedom. In the 20th century, Canada was a refuge for those who opposed military service and for conscientious objectors of the war in Vietnam. In the 21st century, Canada may be a refuge for US Latinos who can no longer tolerate the public and legislative hostility in the US that is directed towards immigrants.

There is ample research on Latinos in the United States and, likewise, a growing body of work on Latinos in Canada. But little research examines Latino migration between the two counties. As the Latino population in the United States continues to grow, their migration to Canada will become a major consideration in Canadian immigration policies with the United States. 
Shihadeh et al.: The third alternative-Latino immigration from the United States to Canada, 1980 to 2009

\section{Acknowledgement}

This study is made possible by funding from the Canadian Studies Faculty Research Grant Program from the International Council on Canadian Studies.

\section{References}

Aguilera, M.B., and D.S. Massey. 2003. Social capital and the wages of Mexican migrants: New hypotheses and tests. Social Forces 82:671-701.

American Community Survey. 2009. 2009 American Community Survey 1-Year Estimates. US Census Bureau. Duplicated.

Armor, J. 2006. The Hazleton Case: The People vs. the ACLU. Canyon Nens, September 10.

The Associated Press. 2009. Shenandoah Teens Cleared of Serious Charges in Beating of Immigrant. http://www.pennlive.com/midstate/index.ssf/2009/05/no_verdict_yet_in_shenandoah_i.html

Bailey, T.R. 1987. Immigrant and Native Workers: Contrasts and Competition. Boulder, CO: Westview Press.

Bernhard, J., P. Landolt, and L. Goldring. 2008. Transnationalizing families: Canadian immigration policy and the spatial fragmentation of care-giving among Latin American newcomers. International Migration 47:3-31.

Box, G., and G.M. Jenkins. 1976. Time Series Analysis: Forecasting and Control. San Francisco: Holden-Day.

Box, G., G.M. Jenkins, and G.C. Reinsel. 1994. Time Series Analysis: Forecasting and Control. 3rd edn. New York: Prentice-Hall.

Brockwell, P.J., and R.A. Davis. 2009. Time Series: Theory and Methods. 2nd edn. New York: Springer.

Calavita, K. 1992. Inside the State: The Bracero Program, Immigration, and the INS. New York: Routledge.

CIA. 2010. Colombia: Transnational issues. World Factbook. https://www.cia.gov/library/publications/ the-world-factbook/geos/co.html

CIC (Citizenship and Immigration Canada). 2010. Facts and Figures. Special Data Request.

CNN. 2011. Missouri Court Rules Immigrant's Adoption Rights Terminated Illegally. http://www.cnn. com/2011/US/01/25/missouri.immigrant.child/index.html?hpt=T2

Cobb-Clark, D.A., C.R. Shiells, and B.L. Lowell. 1995. Immigration reform: The employer sanctions and legalization on wages. Journal of Labor Economics 13:472-498.

Cornelius, W.A., S. Borger, A. Sawyer, D. Keyes, C. Appleby, K. Parks, G. Lozada, and J. Hicken. 2008. Controlling Unauthorized Immigration from Mexico: The Failure of 'Prevention Through Deterrence' and the Need for Comprehensive Reform. San Diego, CA: University of California, San Diego, Center for Comparative Immigration Studies. Duplicated.

DeVoretz, D.J., and S. Laryea. 1997. Are We Losing It? Canada's Brain Drain to the United States: New Evidence from the 1990s. Toronto: C.D. Howe Institute; and Vancouver: Laurier Institution. Duplicated.

Durand, J., and D.S. Massey. 2006. Crossing the Border: Research from the Mexican Migration Project. New York: Russell Sage Foundation Publications. 
Durand, J., D.S. Massey, and F. Chavret. 2000. The changing geography of Mexican immigration to the United States: 1910-1996. Social Science Quarterly 81:1-15.

Globermann, S. 1999. Perspectives on North American Free Trade: Trade Liberalization and the Migration of Skilled Workers. Industry Canada Research Publications Program No. 3. Ottawa: Industry Canada.

Grewal, S. 2007. Latin Boon for Brand Canada: Divisive Immigration Politics in the US are Pushing Talented Latinos Further North. The Star, August 4.

Hagan, J. 2001. Northern Passage: American Vietnam War Resisters in Canada. Cambridge, MA: Harvard University Press.

Hansen, N., and G. Cardenas. 1988. Immigrant and native ethnic enterprises in Mexican American neighborhoods: Differing perceptions of Mexican immigrant workers. International Migration Review 22:226-242.

Iqbal, M. 2000. The Migration of High-Skilled Workers from Canada to the United States: Empirical Evidence and Economic Reasons. San Diego, CA: University of California, San Diego, Center for Comparative Immigration Studies. Duplicated.

Johnson-Webb, K.D. 2002. Employer recruitment and Latino labor migration: North Carolina urban areas at the end of the millennium. The Professional Geographer 54:406-421.

Kalir, B. 2005. The development of a migratory disposition: Explaining a 'new emigration.' International Migration 43(4):165-194.

Kazemipur, A., and S.S. Halli. 2001. Immigrants and 'new poverty:' The case of Canada. International Migration Review 35:1129-1156.

Kochhar, R., R. Suro, and S. Tafoya. 2005. The New Latino South: The Context and Consequences of Rapid Population Growth. Washington, DC: Pew Hispanic Center. Duplicated.

Lapinski, J.S., P. Peltola, G. Shaw, and A. Yang. 1997. The polls—-trends. Public Opinion Quarterly 61:356383.

Livingston, G. 2009. Hispanics, Health Insurance and Health Care Access. Washington, DC: Pew Hispanic Center. Duplicated (September 25).

Lopez, M.H., G. Livingston, and R. Kochhar. Hispanics and the Economic Downturn: Housing Woes and Remittance Cuts. Washington, DC: Pew Hispanic Center. Duplicated (January).

Mahoney, K., M. Thompson, and J. MacSwan. 2004. The condition of English language learners in Arizona, 2004, in The Condition of Pre-K-12 Education in Arizona, 2004, edited by A. Molnar. Tempe, AZ: Education Policy Research Laboratory, Arizona State University, p. 1-27.

Martin, P., and E. Midgley. 2010. Population Bulletin Update. Washington, DC: Population Reference Bureau. Duplicated.

Massey, D.S., J. Durand, and N.J. Malone. 2002. Beyond Smoke and Mirrors: Mexican Immigration in an Era of Economic Integration. New York: Russell Sage Foundation Publications.

McDermott, J. 2003. Colombia Murder Rate Soars. BBC News, 24 April 2003. http:// news.bbc. co.uk/2/hi/americas/2971779.stm

Millman, J., and C. Vitzthum. 2003. Changing Tide: Europe Becomes New Destination for Latino Workers. Wall Street Journal, September 12. 
Shihadeh et al.: The third alternative-Latino immigration from the United States to Canada, 1980 to 2009

Morales, L. 2010. Amid Immigration Debate, Americans' Views Ease Slightly. Gallup, Inc. (July 27).

Nevins, J. 2002. Operation Gatekeeper: The Rise of the 'Tllegal Alien' and the Making of the U.S.-Mexico Boundary. New York: Routledge.

Nossiter, A. 2009. Day Laborers are Easy Prey in New Orleans. The New York Times, February 15.

Padilla, B., and J. Peixoto. 2007. Latino American immigration to Southern Europe. Migration Information Source at: http://www.migrationinformation.org/Feature/display.cfm?ID=609

Pew Hispanic Center. 2007. National Survey of Latinos: As Illegal Immigration Issue Heats Up, Hispanics Feel a Chill. Washington, DC: Pew Hispanic Center. Duplicated (December).

Portes, A., and L. Jensen. 1992. Disproving the enclave hypothesis. American Sociological Review 57:418420.

Preston, J. 2007. Judge Voids Ordinance on Illegal Immigrants. The New York Times, July 27.

. 2008. Large Iowa Meatpacker in Illegal Immigrant Raid Files for Bankruptcy. New York Times, May 11.

Putnam, R. 2000. Bowling Alone: The Collapse and Revival of American Community. New York: Simon and Schuster.

Shihadeh, E.S., and R.E. Barranco. 2013. The imperative of place: Homicide and the new Latino migration. The Sociological Quarterly 54(1):81-104.

Siemiatycki, M. and E. Isin. 1997. Immigration, diversity and urban citizenship in Toronto. Canadian Journal of Regional Science 20(1-2):73-107.

Stasiulis, D. 1995. Deep diversity: Race and ethnicity in Canadian politics. In Canadian Politics in the 1990s, edited by Michael Whittington and Glen Williams. Winnipeg: Nelson.

State of Arizona. 2000. Proposition 203. http://www.azsos.gov/election/2000/info/PubPamphlet/ english/prop203.htm

—. 2010. Senate Bill 1070. http://www.azleg.gov/legtext/49leg/2r/bills/sb1070s.pdf

State of California. 1998. Proposition 227. http://primary98.sos.ca.gov/VoterGuide/Propositions/227. htm

Statistics Canada. 2001. Population and Growth Components (1851-2001 Censuses). Ottawa: Statistics Canada.

—. 2006. Selected Trend Data for Canada, 1996, 2001, and 2006 Censuses. Ottawa: Statistics Canada.

- 2008. Facts and figures 2008 - Immigration overview: Permanent and temporary residents. http://www.cic.gc.ca/english/resources/statistics/facts2008/permanent/21.asp.

— 2010. Labour Force Historical Review 2009. Ottawa: Statistics Canada (Cat. No. 71F0004XVB).

Suro, R. and A. Singer. 2002. Latino Growth in Metropolitan America. Washington, DC: Pew Hispanic Center. Duplicated. 
Thornton, D. 2010. Walking ATM's: A Criminological Examination of Hispanic Robbery Victimization Pre- and Post-Hurricane Katrina in Metropolitan New Orleans. Master's thesis. Department of Sociology, Indiana State University.

US Bureau of Labor Statistics. 2010. Current Population Survey. Washington, DC: United States Department of Labor.

US Census Bureau. 2010. American Fact Finder. Washington, DC: US Census Bureau.

Waters, M. C. 1995. West Indian Immigrants, African Americans and Whites in the Workplace: Different Perspectives on American Race Relations. Paper presented at the American Sociological Association Meeting, Los Angeles (August).

Wilson, W.J. 1996. When Work Disappears: The World of the New Urban Poor. New York: Knopf.

Yoon, I. 1997. On My Own: Korean Businesses and Race Relations in America. Chicago: University of Chicago Press. 